\title{
ENGINEERING GEOLOGICAL AND GEOTECHNICAL INVESTIGATION OF LANDSLIDE EVENTS IN WILDFIRE AFFECTED AREAS OF ILIA PREFECTURE, WESTERN GREECE
}

\author{
Depountis N. ${ }^{1}$, Lainas S. ${ }^{2}$, Pyrgakis D. ${ }^{2}$, Sabatakakis N. ${ }^{2}$, and Koukis G. ${ }^{2}$ \\ ${ }^{1}$ Region of Western Greece, Directorate of Public Works, 26110 Patras, Greece, \\ nikosdepountis@hotmail.com \\ ${ }^{2}$ University of Patras, Department of Geology, Laboratory of Engineering Geology, 26500 Patras, Greece, \\ splainas@upatras.gr
}

\begin{abstract}
In August 2007 Ilia Prefecture suffered one of the most devastating wildfires that have ever happened on European level. Approximately $870 \mathrm{~km}^{2}$, mainly forest and agricultural land, were lost, more than 60 people were killed, hundreds were injured and many villages suffered extensive damage. Heavy rainfall and human activities, favoured by the loss of vegetation and the overall susceptibility of geological formations in landsliding, induced the manifestation or reactivation of various scale landslide phenomena. In order to investigate and mitigate the problem University of Patras was commissioned by the Region of Western Greece to undertake an Engineering Geological and Geotechnical investigation. Site investigation accomplished in seven municipalities focusing on several landslide events with serious socio-economic impact and as a result many small scale cases were identified. In each one of these cases large scale engineering geological mapping was conducted and remedial and protection measures were designed.
\end{abstract}

Key words: Wildfires, Landslides, Geotechnical Investigation, Ilia Prefecture, Western Greece

\section{Introduction}

Few months after the devastating wildfires of August 2007 that affected Ilia Prefecture the University of Patras was commissioned by the Region of Western Greece to undertake an Engineering Geological and Geotechnical investigation, aiming at the treatment of landslide phenomena particularly in seven municipalities that had suffered extensive damage.

The inquiring project titled "Engineering Geological and Geotechnical investigation in wildfire affected Municipalities of the Ilia Prefecture for the identification and treatment of landslide phenomena - Design of landslide hazard mitigation measures " and was supervised by the Department of Transport Works/Directorate of Public Works/Region of Western Greece.

The project was completed in September 2008 and comprised the followings:

a) Identification of all landslide phenomena and failures that occurred in the seven municipalities of the project: Amaliada, Andritsaina, Iardanos, Skillountos Oleni, Pineia, and Foloi. 


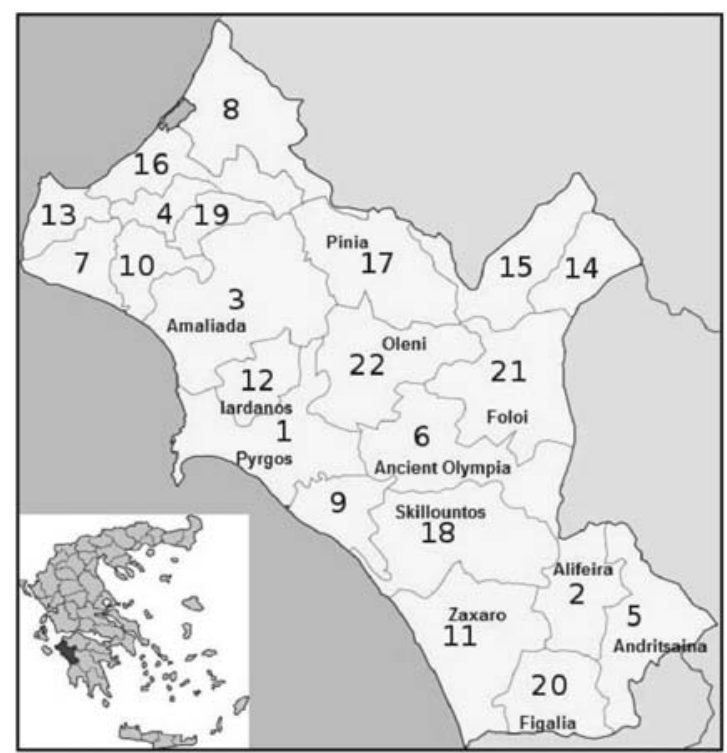

Fig. 1: Investigation area - Municipalities of the Ilia Prefecture.

b) Evaluation of landslide hazard and selection of the most serious cases for further investigation.

c) Engineering geological and geotechnical investigation of forty six (46) landslide cases that seriously affected the human environment.

d) Identification of landslide causes and trigger.

e) Production of technical reports and geotechnical maps as well as design of landslide hazard mitigation measures.

f) Submission of proposals for further investigation.

\section{Investigation area}

The investigation area comprised the Municipalities of Amaliada, Andritsaina, Iardanos, Pinia, Skillountos, Oleni, and Foloi (Fig. 1), occupying a total area of approximately $1115 \mathrm{~km}^{2}$. The total area of the Ilia Prefecture is $2618 \mathrm{~km}^{2}$ and the burnt land estimated to be $870 \mathrm{~km}^{2}$ (approximately $33 \%$ of the total area). The most affected Municipalities were those of the project as well as the Municipalities of Zaxaro, Alifeira, Figalia, and Ancient Olympia (Fig. 1). From the burnt land the bigger percentage included forest and agricultural land as well as residential districts. Further investigation is needed in the Municipalities of Zaxaro, Alifeira, Figaleia, and Arxaia Olympia that were not included in the inquiring project.

\section{Identification of landslide phenomena in the investigation area}

\subsection{Landslide types and causes of movement}

Zaruba and Mencl $(1969,1976)$ and Varnes (1978) have developed the most well known landslide classification Tables. Table 1, was adopted for landslide identification and classification during the project, illustrates a schematic landslide classification (Varnes, 1978) taking into account the modifications made by Cruden and Varnes (1996). Some integration has also been made by using the definitions of Hutchinson (1988), Coates (1977), and Hungr et al. (2001).

According to up to today studies in the Ilia Prefecture have been identified (from 1950 until 


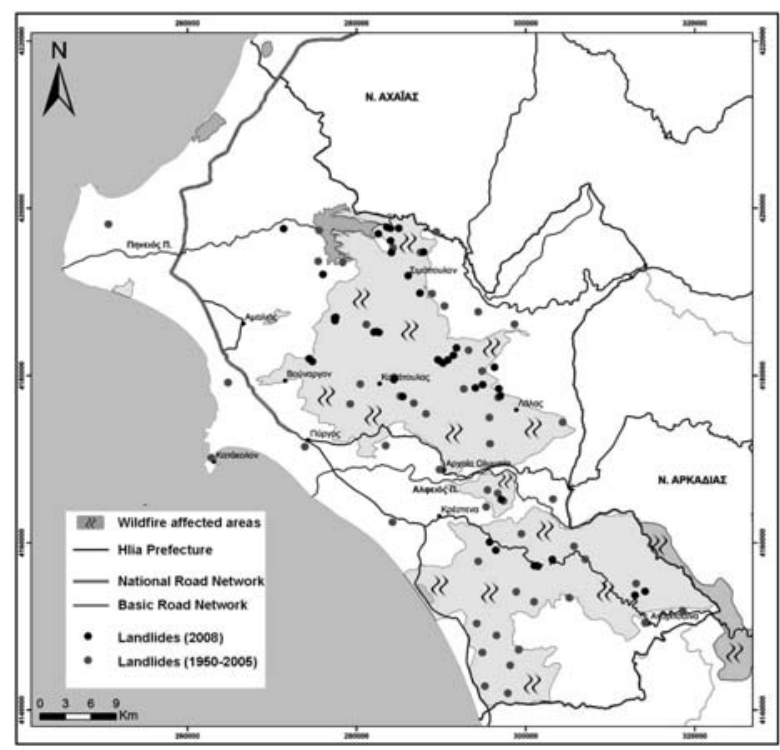

Fig. 2: Landslides identified in the Ilia Prefecture (1950-2005) \& (2008).

Table 1.

\begin{tabular}{|c|c|c|c|c|c|}
\hline \multirow{3}{*}{\multicolumn{3}{|c|}{ Type of movement }} & \multicolumn{3}{|c|}{ Type of material } \\
\hline & & & \multirow[t]{2}{*}{ Bedroc } & \multicolumn{2}{|c|}{ Engineering soils } \\
\hline & & & & $\begin{array}{l}\text { Predominantly } \\
\quad \text { fineg }\end{array}$ & $\begin{array}{c}\text { Predominantly } \\
\text { coarse }\end{array}$ \\
\hline \multicolumn{3}{|l|}{ Falls } & Rockfall & Earth fall & Debris fall \\
\hline \multicolumn{3}{|c|}{ Topples } & Rock topple & Earth topple & Debris topple \\
\hline \multirow{3}{*}{ Slides } & Rotationa & & Rock slump & Earth slump & Debris slump \\
\hline & \multirow{2}{*}{$\begin{array}{l}\text { Transla- } \\
\text { tional }\end{array}$} & Few units & Rock block slide & Earth block slide & Debris block slide \\
\hline & & Many units & Rock slide & Earth slide & Debris slide \\
\hline \multicolumn{3}{|c|}{ Lateral spreads } & Rock spread & Earth spread & Debris spread \\
\hline \multirow{3}{*}{\multicolumn{3}{|c|}{ Flows }} & Rock flow & Earth flow & Debris flow \\
\hline & & & Rock avalanche & & Debris avalanche \\
\hline & & & (Deep creep) & (Soil creep) & \\
\hline \multicolumn{3}{|c|}{ Complex and compound } & \multicolumn{3}{|c|}{ Combination in time or space of two or more principal types of movement } \\
\hline
\end{tabular}

2005) fifty eight (58) landslides (Fig. 2) of intermediate and high vulnerability. Thirty seven (37) of them (percentage 64\%) are located in the investigation area, affected by the wildfires of August 2007. Therefore, many of them were expected to be reactivated with bigger intensity, because of the unfavourable conditions that prevailed after the wildfires.

During the current investigation forty six (46) landslide cases (Fig. 2) that seriously affected the human environment, of intermediate and high vulnerability, most of them existed before, were thoroughly investigated and an identification of the main types and causes of movement was made (Table 2) by using the previous landslide classification of Table 1 . 
Table 2.

\begin{tabular}{|c|c|c|c|}
\hline No & Location & Main types of movement & Main causes of movement \\
\hline & Amaliada & & \\
\hline 1 & Keramidia village & $\begin{array}{l}\text { Road embankment failure/ } \\
\text { Earth Slump and Flow }\end{array}$ & $\begin{array}{l}\text { Weathering of soils/ } \\
\text { Undercutting }\end{array}$ \\
\hline 2 & Peristeri village road entrance & Earth Slump - Soil Creep & Weathering of soils \\
\hline 3 & Peristeri village & $\begin{array}{l}\text { Road embankment failure/ } \\
\text { Earth Slump and Flow }\end{array}$ & $\begin{array}{l}\text { Weathering of soils/ } \\
\text { Loading }\end{array}$ \\
\hline 4 & Peristeri Elementary school & Soil Creep & Weathering of soils \\
\hline 5 & Provincial road Peristeri-Inoi & $\begin{array}{l}\text { Road embankment failure/ } \\
\text { Earth Slump and Flow }\end{array}$ & $\begin{array}{l}\text { Weathering of soils/ } \\
\text { Undercutting \& Loading }\end{array}$ \\
\hline \multirow[t]{2}{*}{6} & North of Pinios Lake - Earth dam & Earth Slump & Undercutting \& Excavation \\
\hline & Andritsaina & & \\
\hline 7 & Miloi village & Rock Falls and Flow & Weathering of jointed rocks \\
\hline 8 & Sikies village & Earth Slump & Fluvial erosion \\
\hline \multirow[t]{2}{*}{9} & Provincial road Andritsaina-Sekoulas & Debris Flow & Fluvial erosion \\
\hline & Iardanos & & \\
\hline 10 & Mun. road Vounargo-Fragkopidima & Rock Falls/Earth Slides & $\begin{array}{l}\text { Weathering of soft rocks/ } \\
\text { Steep slopes \& Excavation }\end{array}$ \\
\hline 11 & Provincial road Vroxitsa-Korifi & Earth Flow & Weathering of soils \\
\hline \multirow[t]{2}{*}{12} & Provincial road Vroxitsa-Korifi & Road embankment failure & Weathering of soils \\
\hline & Pinia & & \\
\hline 13 & Latta village & Earth Slump and Flow & Weathering of soils \\
\hline 14 & Valmi village & Earth Slump & Weathering of soils \\
\hline 15 & Municipal road Valmi-Apidoula & $\begin{array}{l}\text { Earth Slides and Falls } \\
\text { Debris Slides and Falls }\end{array}$ & $\begin{array}{l}\text { Weathering of soils/ } \\
\text { Undercutting }\end{array}$ \\
\hline 16 & Provincial road Valmi-Xenies & Debris Slides and Falls & $\begin{array}{l}\text { Weathering of soft rocks/ } \\
\text { Steep slopes \& Excavation }\end{array}$ \\
\hline 17 & Provincial road Valmi-Agrapidoxori & Earth Falls & $\begin{array}{l}\text { Weathering of soils/ } \\
\text { Fluvial erosion }\end{array}$ \\
\hline 18 & Agrapidoxori village road entrance & $\begin{array}{l}\text { Road embankment failure/ } \\
\text { Earth Flow }\end{array}$ & $\begin{array}{l}\text { Weathering of soils/ } \\
\text { Undercutting }\end{array}$ \\
\hline 19 & Simopoulo village road entrance & Earth Flow & Undercutting \\
\hline 20 & Agnanta village & Earth Slides and Flow & $\begin{array}{l}\text { Weathering of soils/ } \\
\text { Steep slopes }\end{array}$ \\
\hline 21 & Kotrona hamlet & Soil Creep & Undercutting \\
\hline 22 & Mazaraki village & Earth Slides and Flow & Weathering of soils \\
\hline 23 & Kalo Paidi village & $\begin{array}{l}\text { Earth Slumps and Flow } \\
\text { Debris Slides and Flow }\end{array}$ & $\begin{array}{l}\text { Weathering of soils/ } \\
\text { Undercutting \& Loading }\end{array}$ \\
\hline
\end{tabular}




\begin{tabular}{|c|c|c|c|}
\hline No & Location & Main types of movement & Main causes of movement \\
\hline & Skillountos & & \\
\hline 24 & Graika village & Earth and Debris Flow & Weathering of soils \\
\hline 25 & Grillos cillage & Soil Creep & Weathering of soils \\
\hline 26 & Platiana village & $\begin{array}{l}\text { Rock Slides and Falls } \\
\text { Earth and Debris Slides }\end{array}$ & $\begin{array}{l}\text { Weathering of jointed } \\
\text { rocks/Steep slopes }\end{array}$ \\
\hline 27 & $\begin{array}{l}\text { Municipal road Platiana - Archaeolog- } \\
\text { ical site }\end{array}$ & $\begin{array}{l}\text { Rock Slides and Falls } \\
\text { Earth Slumps - Debris Falls }\end{array}$ & $\begin{array}{l}\text { Weathering of jointed } \\
\text { rocks/Steep slopes \& Ex- } \\
\text { cavation }\end{array}$ \\
\hline 28 & Municipal road to Tripiti & $\begin{array}{l}\text { Road embankment failure/ } \\
\text { Earth Slump and Flow }\end{array}$ & $\begin{array}{l}\text { Weathering of soils/ } \\
\text { Undercutting }\end{array}$ \\
\hline 29 & Provincial road Krestena-Graika & $\begin{array}{l}\text { Road embankment failure/ } \\
\text { Earth Slump }\end{array}$ & $\begin{array}{l}\text { Fluvial erosion/ } \\
\text { Undercutting }\end{array}$ \\
\hline 30 & Frixa village & $\begin{array}{l}\text { Earth Slumps and Flow } \\
\text { Earth Slides }\end{array}$ & $\begin{array}{l}\text { Weathering of soils/ } \\
\text { Fluvial erosion \& Loading }\end{array}$ \\
\hline \multirow[t]{2}{*}{31} & Frixa village road entrance & $\begin{array}{l}\text { Road embankment failure/ } \\
\text { Earth Slide }\end{array}$ & $\begin{array}{l}\text { Weathering of soils/ } \\
\text { Excavation }\end{array}$ \\
\hline & Oleni & & \\
\hline 32 & Rural road Goumero-Askitis & $\begin{array}{l}\text { Rock Falls } \\
\text { Earth Slides and Flow }\end{array}$ & $\begin{array}{l}\text { Weathering of soft rocks/ } \\
\text { Steep slopes \& Excavation }\end{array}$ \\
\hline 33 & $\begin{array}{l}\text { Municipal road Goumero-Agia Anna } \\
\text { (Vrisi) }\end{array}$ & $\begin{array}{l}\text { Road embankment failure/ } \\
\text { Earth Slump and Flow }\end{array}$ & $\begin{array}{l}\text { Weathering of soils/ } \\
\text { Excavation }\end{array}$ \\
\hline 34 & $\begin{array}{l}\text { Municipal road Goumero-Agia Anna } \\
\text { (Koukos) }\end{array}$ & $\begin{array}{l}\text { Road embankment failure/ } \\
\text { Debris Slump }\end{array}$ & $\begin{array}{l}\text { Weathering of soils/ } \\
\text { Excavation }\end{array}$ \\
\hline 35 & Goumero village road entance & Earth Slide & Weathering of soils \\
\hline 36 & Agia Anna village & Debris Slide & Weathering of soils \\
\hline 37 & Agios Georgios village & Earth Slide & $\begin{array}{l}\text { Weathering of soft rocks/ } \\
\text { Loading }\end{array}$ \\
\hline 38 & Municipal road Koutsoxera-Mouzaki & $\begin{array}{l}\text { Road embankment failure/ } \\
\text { Earth Flow }\end{array}$ & Weathering of soils \\
\hline 39 & Koutsoxera church & Earth Slide & $\begin{array}{l}\text { Weathering of soft rocks/ } \\
\text { Loading }\end{array}$ \\
\hline 40 & Koutsoxera Primary school & Earth Flow - Soil Creep & $\begin{array}{l}\text { Weathering of soils/ } \\
\text { Loading }\end{array}$ \\
\hline \multirow[t]{2}{*}{41} & Provincial road Oleni-Magoula & Earth Slide and Flow & $\begin{array}{l}\text { Weathering of soils/ } \\
\text { Excavation }\end{array}$ \\
\hline & Foloi & & \\
\hline 42 & Doukas village & Earth Slump and Flow & Weathering of soils \\
\hline 43 & Milies village & Earth and Debris Flow & $\begin{array}{l}\text { Weathering of soils/ } \\
\text { Excavation }\end{array}$ \\
\hline 44 & Provincial road in Avra springs & Rock and Debris Falls & Fluvial erosion/Undercutting \\
\hline 45 & Neraida village & Rock Slides \& Falls & Weathering of jointed rocks \\
\hline 46 & Nea Persaina village & Earth Flow - Soil Creep & Weathering of soils \\
\hline
\end{tabular}




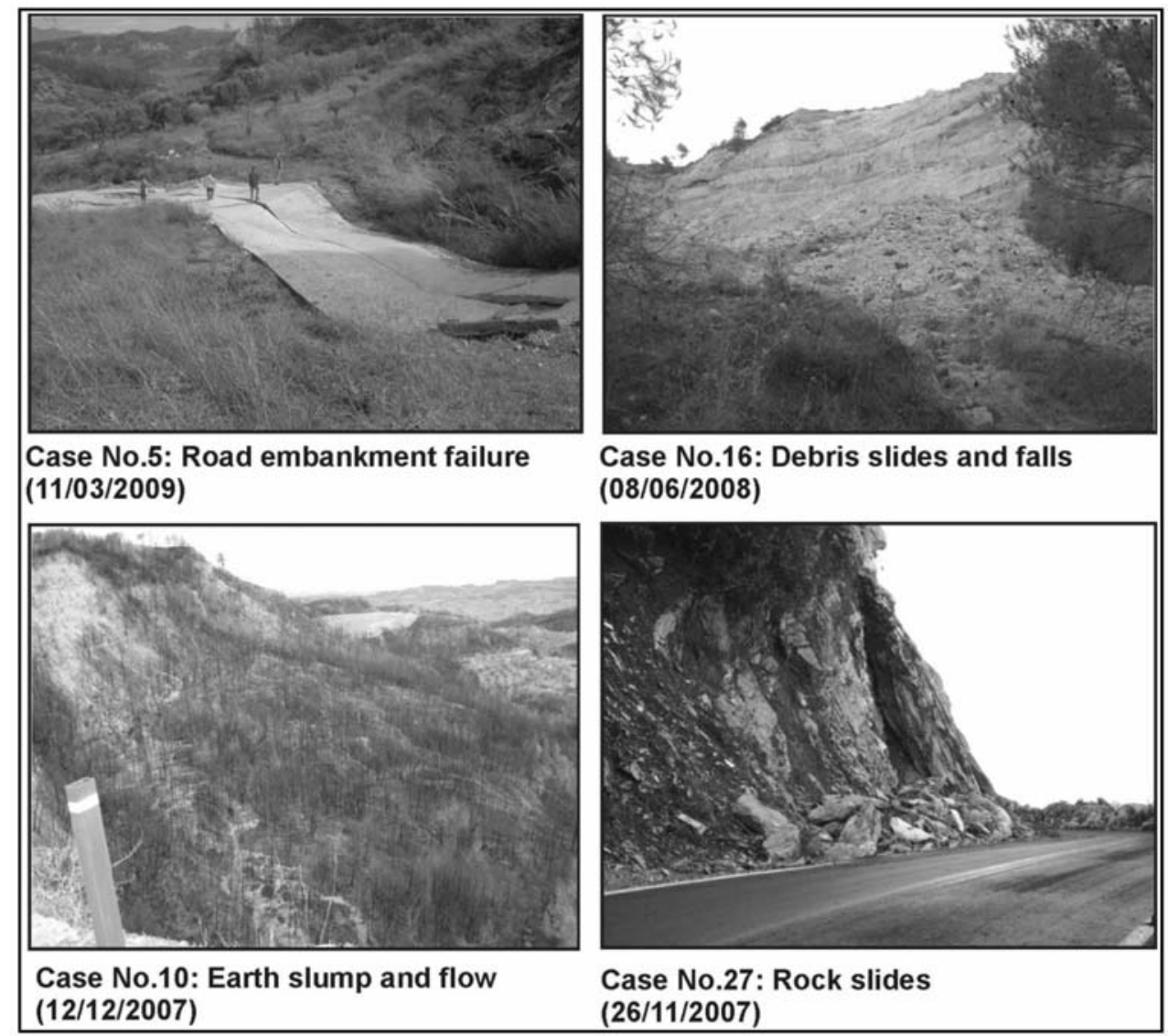

Fig. 3: Landslides identified in the Ilia Prefecture (1950-2005) \& (2008).

The primary cause of movement in most of the cases of Table 2 was the loss of vertical vegetative and forestry structure after the wildfires. In shallow and poor soils the removal of deeprooted vegetation was crucial and destabilized the already fragile slopes and as a result many landslides that existed before reactivated. The main trigger of landslide reactivation was either the intense rainfall or in some cases $(7,15,16)$ a combination of rainfall and seismic activity. Concerning the main causes of movement, according to Table 2, was the intense weathering of soils, soft rocks and hard rocks as well as:

- Excavation created by human activities mainly for the construction of roads and houses.

- Undercutting created either by human activities or physical processes.

- Loading created by human activities or excess pore water pressure after an intense rainfall

- Fluvial erosion created by rivers and streams causing loss of support on the toe of generally steep slopes or along the river/stream banks.

All landslide cases were located with precise coordinates in maps of suitable scale and the forty six (46) of them are presented in Fig. 2 along with those occurred during the period 1950-2005. 


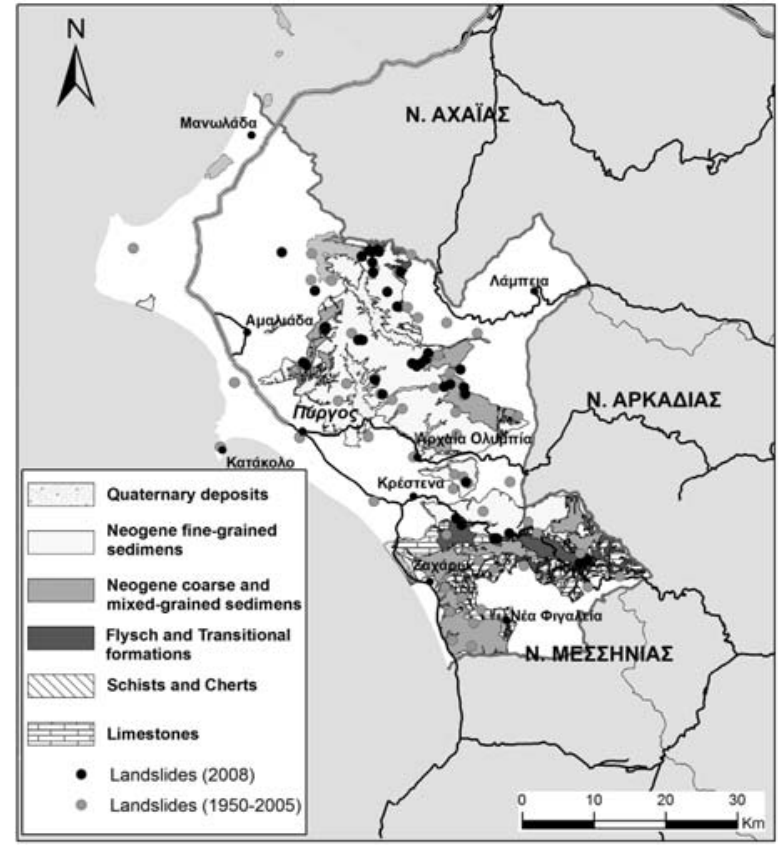

Fig. 4: Engineering Geological conditions and landslides in the Ilia Prefecture.

\subsection{Effect of Engineering Geological conditions on landslide movement}

The identified 46 landslide cases were occurred mainly with a complex type of movement (falls, slides, and flow) and affected by the prevailed geological formations. Earth flow, slumps, slides, and soil creeps were occurred mainly in the fine Neogenic sediments which dominate in the area. Debris slides and flow were occurred mainly in the coarse Neogenic sediments, whereas rock falls and slides as well as debris falls were activated in limestones and sandstones (Fig. 3).

All these landslides were triggered by heavy rainfall and/or seismic activity favoured by the loss of vegetation after the wildfires and the overall susceptibility of the prevailed geological formations in landsliding (Fig. 4). The geological formations of the Neogenic sediments constituted by weathered soft rocks of sandy-silt constitution, friable sandstones, and poor soils of sandy-silt constitution are prone in earth flow, slumps and slides as well as rock and debris falls and slides. In addition the jointed rocks of the limestone bedrock produce heavy rock falls and slides.

The prevailed engineering geological conditions combined with the loss of vegetation, the deforestation and the intense rainfalls contributed in the deterioration of landslide problem. However, in many cases the horizontal stratigraphy combined with the prevailed low relief produced landslides in such a scale that can be treated with protection measures economically and technically feasible provided that they will be faced in time.

\section{Proposed remedial and protection measures}

The proposed remedial and protection measures aiming at the treatment of landslide phenomena in the Ilia Prefecture can be summarized in the following paragraphs and Table 3:

a) Surface drainage works with the construction of surface or shallow drains, as well as diversion ditches of rain-storm waters along the road network. Surface drains includes concrete 
Table 3.

\begin{tabular}{|c|c|c|c|}
\hline No & Location & Main types of movement & Main causes of movement \\
\hline & Amaliada & & \\
\hline 1 & Keramidia village & $\begin{array}{l}\text { Road embankment failure/ } \\
\text { Earth Slump and Flow }\end{array}$ & $\begin{array}{l}\text { Drainage works/Gabion wall/ } \\
\text { Ground improvement }\end{array}$ \\
\hline 2 & Peristeri village road entrance & Earth Slump - Soil Creep & Surface drainage \\
\hline 3 & Peristeri village & $\begin{array}{l}\text { Road embankment failure/ } \\
\text { Earth Slump and Flow }\end{array}$ & $\begin{array}{l}\text { Drainage works/Driven-pile } \\
\text { wall/Ground improvement }\end{array}$ \\
\hline 4 & Peristeri Elementary school & Soil Creep & Surface drainage/Gravity wall \\
\hline 5 & Provincial road Peristeri-Inoi & $\begin{array}{l}\text { Road embankment failure/ } \\
\text { Earth Slump and Flow }\end{array}$ & $\begin{array}{l}\text { Drainage/Gabion wall/ } \\
\text { Ground improvement/Un- } \\
\text { loading }\end{array}$ \\
\hline \multirow[t]{2}{*}{6} & North of Pinios Lake - Earth dam & Earth Slump & $\begin{array}{l}\text { Surface drainage/Gabion } \\
\text { wall/Driven-pile wall/ } \\
\text { Rescaling }\end{array}$ \\
\hline & Andritsaina & & \\
\hline 7 & Miloi village & Rock Falls and Flow & $\begin{array}{l}\text { Surface drainage/Rockfall } \\
\text { barrier/Rock scaling }\end{array}$ \\
\hline 8 & Sikies village & Earth Slump & Drainage works/Gabion wall \\
\hline \multirow[t]{2}{*}{9} & Provincial road Andritsaina-Sekoulas & Debris Flow & Surface drainage/Gravity wall \\
\hline & Iardanos & & \\
\hline 10 & Mun. road Vounargo-Fragkopidima & Rock Falls/Earth Slides & Surface drainage/Geogrids \\
\hline 11 & Provincial road Vroxitsa-Korifi & Earth Flow & Surface drainage/Vegetation \\
\hline \multirow[t]{2}{*}{12} & Provincial road Vroxitsa-Korifi & Road embankment failure & Drainage works \\
\hline & Pinia & & \\
\hline 13 & Latta village & Earth Slump and Flow & Drainage works \\
\hline 14 & Valmi village & Earth Slump & Surface drainage \\
\hline 15 & Municipal road Valmi-Apidoula & $\begin{array}{l}\text { Earth Slides and Falls } \\
\text { Debris Slides and Falls }\end{array}$ & $\begin{array}{l}\text { Surface drainage/Gravity } \\
\text { walls/Driven-pile wall }\end{array}$ \\
\hline 16 & Provincial road Valmi-Xenies & Debris Slides and Falls & $\begin{array}{l}\text { Surface drainage/ } \\
\text { Gravity wall/Geogrids }\end{array}$ \\
\hline 17 & Provincial road Valmi-Agrapidoxori & Earth Falls & Surface drainage/Geogrids \\
\hline 18 & Agrapidoxori village road entrance & $\begin{array}{l}\text { Road embankment failure/ } \\
\text { Earth Flow }\end{array}$ & $\begin{array}{l}\text { Surface drainage/ } \\
\text { Gabion wall }\end{array}$ \\
\hline 19 & Simopoulo village road entrance & Earth Flow & $\begin{array}{l}\text { Surface drainage/Gabion } \\
\text { wall }\end{array}$ \\
\hline 20 & Agnanta village & Earth Slides and Flow & Surface drainage/Vegetation \\
\hline 21 & Kotrona hamlet & Soil Creep & Surface drainage \\
\hline 22 & Mazaraki village & Earth Slides and Flow & Surface drainage \\
\hline 23 & Kalo Paidi village & $\begin{array}{l}\text { Earth Slumps and Flow } \\
\text { Debris Slides and Flow }\end{array}$ & $\begin{array}{l}\text { Drainage works/Gabion } \\
\text { walls/Gravity walls/Dri- } \\
\text { ven-pile wall }\end{array}$ \\
\hline
\end{tabular}




\begin{tabular}{|c|c|c|c|}
\hline No & Location & Main types of movement & Main causes of movement \\
\hline & Skillountos & & \\
\hline 24 & Graika village & Earth and Debris Flow & Surface drainage \\
\hline 25 & Grillos cillage & Soil Creep & Surface drainage \\
\hline 26 & Platiana village & $\begin{array}{l}\text { Rock Slides and Falls } \\
\text { Earth and Debris Slides }\end{array}$ & $\begin{array}{l}\text { Surface drainage/Gabion } \\
\text { wall/Rockfall barrier/Rock } \\
\text { scaling }\end{array}$ \\
\hline 27 & $\begin{array}{l}\text { Municipal road Platiana - Archaeo- } \\
\text { logical site }\end{array}$ & $\begin{array}{l}\text { Rock Slides and Falls } \\
\text { Earth Slumps - Debris Falls }\end{array}$ & $\begin{array}{l}\text { Surface drainage/Gabion } \\
\text { wall Gravity walls/Unload- } \\
\text { ing }\end{array}$ \\
\hline 28 & Municipal road to Tripiti & $\begin{array}{l}\text { Road embankment failure/ } \\
\text { Earth Slump and Flow }\end{array}$ & $\begin{array}{l}\text { Surface drainage/ } \\
\text { Gabion wall }\end{array}$ \\
\hline 29 & Provincial road Krestena-Graika & $\begin{array}{l}\text { Road embankment failure/ } \\
\text { Earth Slump }\end{array}$ & $\begin{array}{l}\text { Surface drainage/ } \\
\text { Gabion wall }\end{array}$ \\
\hline 30 & Frixa village & $\begin{array}{l}\text { Earth Slumps and Flow } \\
\text { Earth Slides }\end{array}$ & Moving of population \\
\hline \multirow[t]{2}{*}{31} & Frixa village road entrance & $\begin{array}{l}\text { Road embankment failure/ } \\
\text { Earth Slide }\end{array}$ & $\begin{array}{l}\text { Surface drainage/Gabion } \\
\text { wall/ Ground improvement }\end{array}$ \\
\hline & Oleni & & \\
\hline 32 & Rural road Goumero-Askitis & $\begin{array}{l}\text { Rock Falls } \\
\text { Earth Slides and Flow }\end{array}$ & $\begin{array}{l}\text { Surface drainage/Unload- } \\
\text { ing/Rock scaling }\end{array}$ \\
\hline 33 & $\begin{array}{l}\text { Municipal road Goumero-Agia Anna } \\
\text { (Vrisi) }\end{array}$ & $\begin{array}{l}\text { Road embankment failure/ } \\
\text { Earth Slump and Flow }\end{array}$ & $\begin{array}{l}\text { Drainage works/Gabion } \\
\text { wall }\end{array}$ \\
\hline 34 & $\begin{array}{l}\text { Municipal road Goumero-Agia Anna } \\
\text { (Koukos) }\end{array}$ & $\begin{array}{l}\text { Road embankment failure/ } \\
\text { Debris Slump }\end{array}$ & Surface drainage \\
\hline 35 & Goumero village road entance & Earth Slide & Surface drainage \\
\hline 36 & Agia Anna village & Debris Slide & Rescaling \\
\hline 37 & Agios Georgios village & Earth Slide & $\begin{array}{l}\text { Surface drainage/Ground } \\
\text { improvement }\end{array}$ \\
\hline 38 & $\begin{array}{l}\text { Municipal road Koutsoxera- } \\
\text { Mouzaki }\end{array}$ & $\begin{array}{l}\text { Road embankment failure/ } \\
\text { Earth Flow }\end{array}$ & $\begin{array}{l}\text { Surface drainage/Ground } \\
\text { improvement }\end{array}$ \\
\hline 39 & Koutsoxera church & Earth Slide & Gravity wall \\
\hline 40 & Koutsoxera Primary school & Earth Flow - Soil Creep & $\begin{array}{l}\text { Drainage works/Gabion } \\
\text { walls }\end{array}$ \\
\hline \multirow[t]{2}{*}{41} & Provincial road Oleni-Magoula & Earth Slide and Flow & $\begin{array}{l}\text { Surface drainage/Gabion } \\
\text { wall }\end{array}$ \\
\hline & Foloi & & \\
\hline 42 & Doukas village & Earth Slump and Flow & Surface drainage \\
\hline 43 & Milies village & Earth and Debris Flow & Surface drainage/Vegetation \\
\hline 44 & Provincial road in Avra springs & Rock and Debris Falls & $\begin{array}{l}\text { Rock scaling/Gabion wall/ } \\
\text { Suspended netting }\end{array}$ \\
\hline 45 & Neraida village & Rock Slides \& Falls & Rockfall barrier \\
\hline 46 & Nea Persaina village & Earth Flow - Soil Creep & Surface drainage \\
\hline
\end{tabular}




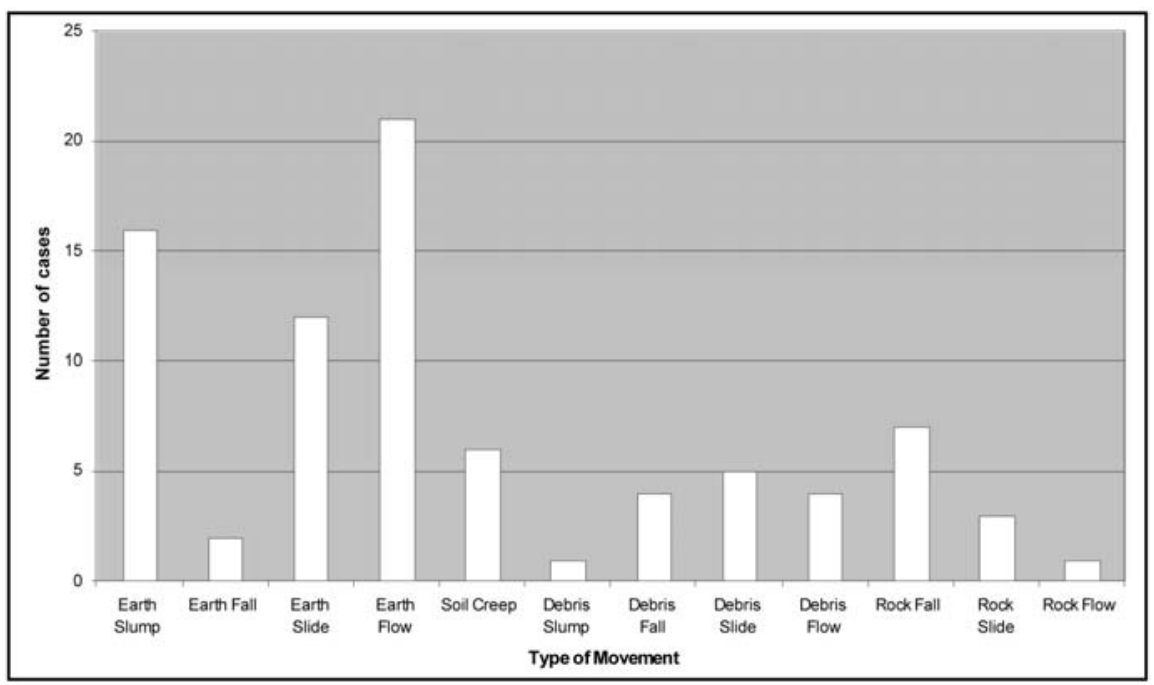

Fig. 5: Main types of landslide movement.

diversion ditches, whereas shallow-interception drains includes perforated tubes covered by granular material in trenches up to $2 \mathrm{~m}$ deep lined with geotextiles.

b) Subsurface drainage works with the construction of drainage trenches up to $3 \mathrm{~m}$ deep and $1 \mathrm{~m}$ wide, as well as drainage blankets up to $1 \mathrm{~m}$ thick on top of the base of road embankments in order to reduce water infiltration and divert quickly subsurface water away of the problem.

c) Construction of retaining walls, usually concrete gravity walls and gabion walls. Gravity walls were proposed to be constructed on small slopes or small parts of large slopes in cases of solid ground. Gabion walls were proposed in cases of small slopes and road embankments as toe weight. Driven pile-walls were proposed to be constructed in cases of deep slide problems.

d) Rockfall barriers were proposed for construction in cases 7, 25, 45, where steep rocky slopes of a great height prone to rock falls and slides were existed, in order to protect residential areas.

e) Ground improvement which includes development of vegetation, geotextiles, geogrids in soil slopes or road embankments that have failed due to poor substratum conditions. Vegetation cover was proposed to reduce water infiltration and provide tensile strength in surface layers. Anchored geotextiles or geogrids were proposed in cases to fix fragile surface slopes and allow plant growth.

f) Slope modification by unloading or rescaling soil slopes and scaling rock slopes.

\section{Conclusions}

All landslide cases activated or reactivated mainly with a complex type of movement (Fig. 5). Earth flow, slumps, slides, and soil creeps were occurred in the fine Neogenic sediments. Debris slides and flow were occurred in the coarse Neogenic sediments, whereas rock falls and slides as well as debris falls were activated in limestones and sandstones.

All landslides were triggered by heavy rainfall and/or seismic activity. The prevailed engineering geological conditions combined with the loss of vegetation, the deforestation, the in- 


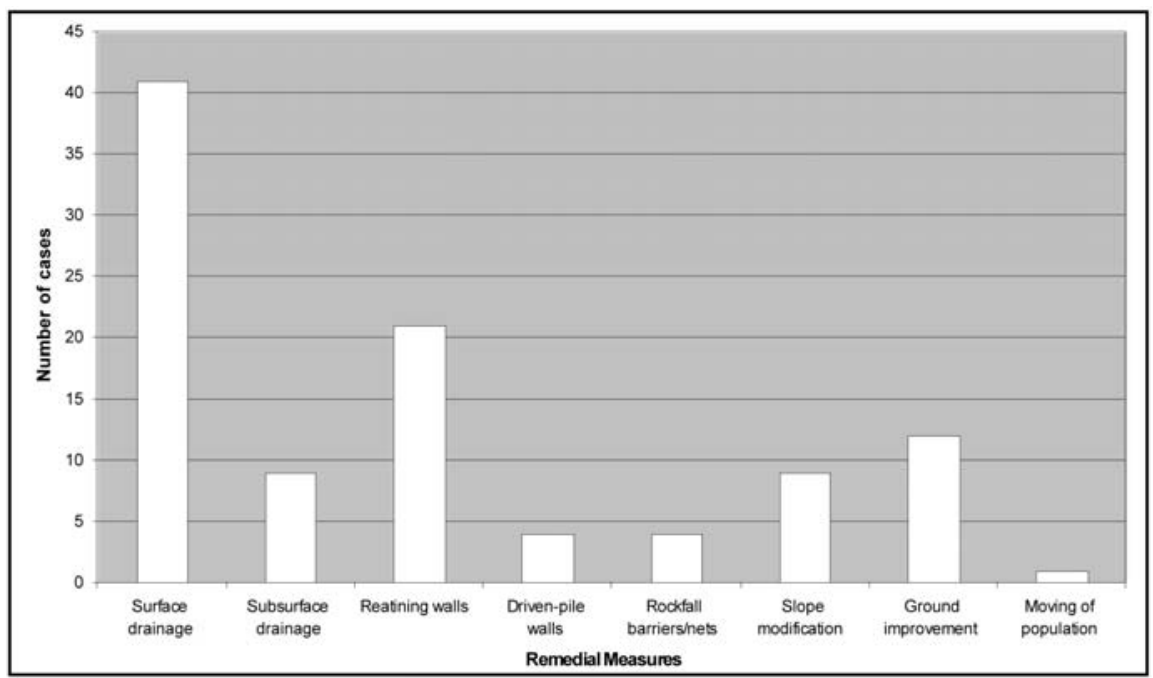

Fig. 6: Remedial and protection measures of landslide cases.

creased weathering and the intense rainfalls contributed in the deterioration of landslide problem. Human activities and fluvial erosion in some cases increased the landslide problem.

All remedial and protection measures proposed for landslide treatment are illustrated in Fig. 6 and mainly include surface and subsurface drainage works combined in many cases with the construction of retaining walls. The other main type of remedial works includes ground improvement and rockfall barriers for the protection of residential areas.

\section{Acknowledgments}

The work was carried out under the support of the Region of Western Greece. The authors wish to express their sincere appreciation to its generous support.

\section{References}

Coates, D.R. 1977. Landslide prospectives. In: Landslides, Geological Society of America, p.3-38.

Cruden D.M., and Varnes, D.J. 1996. Landslide Types and Processes. In: Turner, A.K., and Schuster, R. L., Eds. Landslides: Investigation and Mitigation. Transportation Research Board, Special Report 247, National Research Council, Washington D.C., pp. 36-75.

Hungr, O, Evans, S.G., Bovis, M, and Hutchinson, J.N. 2001. Review of the classification of landslides of the flow type. Environmental and Engineering Geoscience, VII, pp. 221-238.

Hutchinson, J.N. 1988. General Report: Morphological and Geotechnical Parameters of Landslides in Relation to Geology and Hydrogeology. In: Proc. Fifth International Symposium on Landslides (C. Bonnard, ed.), A.A. Balkema, Rotterdam. Netherlands, Vol. 1, pp. 3-35.

Varnes, D.J. 1978. Slope movement types and processes. In: Schuster, R. L., and Krizek, R. J., Eds. Landslides: Analysis and Control. Transportation Research Board, Special Report 176, National Research Council, Washington D.C., pp. 12-33.

Zaruba, Q., and Mencl, V. 1969. Landslides and their control. Elsevier, Amsterdam, 205 pp.

Zaruba, Q. and Mencl, V. 1976. Engineering Geology. Elsevier, Amsterdam, 504 pp. 